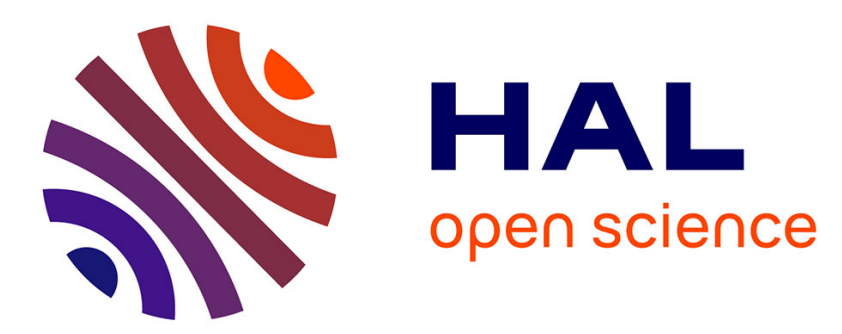

\title{
Biodiversity and litter decomposition: a case study in a Mediterranean stream
}

\author{
Jérémy Jabiol, Eric Chauvet
}

\section{To cite this version:}

Jérémy Jabiol, Eric Chauvet. Biodiversity and litter decomposition: a case study in a Mediterranean stream. Freshwater Science, 2015, vol. 34 (n²), pp. 423-430. 10.1086/680094 . hal-01186542

\section{HAL Id: hal-01186542 \\ https://hal.science/hal-01186542}

Submitted on 25 Aug 2015

HAL is a multi-disciplinary open access archive for the deposit and dissemination of scientific research documents, whether they are published or not. The documents may come from teaching and research institutions in France or abroad, or from public or private research centers.
L'archive ouverte pluridisciplinaire HAL, est destinée au dépôt et à la diffusion de documents scientifiques de niveau recherche, publiés ou non, émanant des établissements d'enseignement et de recherche français ou étrangers, des laboratoires publics ou privés. 


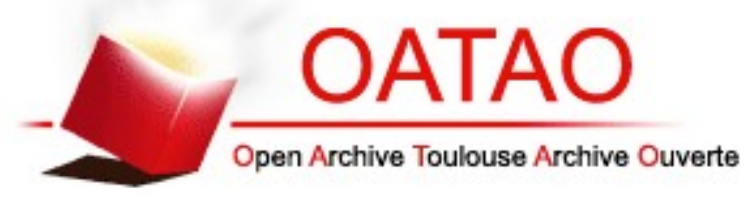

\section{Open Archive TOULOUSE Archive Ouverte (OATAO)}

OATAO is an open access repository that collects the work of Toulouse researchers and makes it freely available over the web where possible.

This is an author-deposited version published in : http://oatao.univ-toulouse.fr/ Eprints ID : 14198

To link to this article : DOI:10.1086/680094

URL : http://dx.doi.org/10.1086/680094

To cite this version : Jabiol, Jérémy and Chauvet, Eric Biodiversity and litter decomposition: a case study in a Mediterranean stream. (2015) Freshwater Science, vol. 34 (n 2). pp. 423-430. ISSN 21619549

Any correspondance concerning this service should be sent to the repository administrator: staff-oatao@listes-diff.inp-toulouse.fr 


\title{
Biodiversity and litter decomposition: a case study in a Mediterranean stream
}

\author{
Jérémy Jabiol ${ }^{1,2,3}$ and Eric Chauvet ${ }^{1,2,4}$ \\ ${ }^{1}$ Université de Toulouse, UPS, INP, EcoLab (Laboratoire écologie fonctionnelle et environnement), 118 route de Narbonne, F-31062 \\ Toulouse, France \\ ${ }^{2}$ National Centre for Scientific Research (CNRS), Ecolab, F-31062 Toulouse, France
}

\begin{abstract}
The importance of riparian diversity for the functioning of headwater streams has been demonstrated repeatedly. For example, mixing litter from different riparian tree species can influence their decomposition rates, an effect that is contingent on both the litter assemblage and the detritivore community. However, the effects of mixing litter species have been studied mostly in temperate streams, and very few studies have been done in nontemperate streams. Mediterranean streams are often subjected to recurrent flow intermittency, and their riparian tree and stream detritivore communities have unique sets of species and traits, which probably influence the effects of litter mixtures on decomposition. We hypothesized that high dissimilarity in litter traits could promote effects of litter mixtures on decomposition that would be counteracted by the low abundance and small body size of detritivores in Mediterranean streams. We manipulated litter diversity and the size-class and presence/absence of detritivores in a $2^{\text {nd }}$-order Mediterranean stream in a 46-d experiment and found substantial but contingent effects on litter mixtures. Mixture effects were not significant on average, but both negative and positive effects of litter mixtures occurred. For instance, mixing soft and nutrient-rich litter species led to up to $9.6 \%$ increase in leaf mass loss. Microbial activity accounted for $85 \%$ of total leaf mass loss, and no effect of litter mixture was observed when detritivores were excluded. In contrast, the presence of detritivores, despite their relatively low abundance and diversity, was a key factor for litter decomposition and promoted effects of litter mixture. These results suggest that the extinction of a few key taxa (riparian tree species or large detritivores) could impair nutrient and $\mathrm{C}$ cycling in Mediterranean streams with potential consequences for stream food webs.

Key words: Mediterranean streams, litter decomposition, diversity effects, shredders, body size
\end{abstract}

Plant-litter decomposition is one of the most important ecosystem processes that allow nutrients and $\mathrm{C}$ recycling (Cebrian 1999). It supports diverse food webs in many ecosystems, including forest soils and woodland headwater streams (Wallace et al. 1997). The importance of this process for the functioning of ecosystems has led many authors to investigate the factors that influence the rate of leaf-litter decomposition (e.g., Leroy and Marks 2006, Berg and McClaugherty 2008). These studies provided evidence that rates of leaf-litter decomposition are influenced primarily by litter physicochemical properties, such as nutrient (e.g., N, P) content, which may enhance decomposition, or structural compound (e.g., lignin) content, which may decrease the rate of decomposition (Melillo et al. 1982, Gessner and Chauvet 1994). However, leaves from a given plant species decompose at different rates depending on whether they are surrounded by leaves from conspecifics or from other plant species (Hättenschwiler et al. 2005, Lecerf et al. 2007, Gessner et al. 2010). This litter-mixture effect has received considerable attention in stream ecosystems, and several mechanisms that may give rise to the effects of mixing litter on decomposition have been identified. Some of them are purely physical (e.g., decreased physical abrasion of soft litter when protected by structurally stable litter; Swan and Palmer 2004, Swan et al. 2008), but most involve the activity of detritus-feeding macroinvertebrates (Swan and Palmer 2006, SanperaCalbet et al. 2009), potentially through their interaction with microorganisms (Jabiol and Chauvet 2012). For instance, preferential feeding on certain litter species in a mixture explained its increased decomposition in laboratory experiments (Swan and Palmer 2006). Moreover, the presence of slow-decomposing and structurally rich litter in mixtures might increase detritivore activity by creating a long-lived and structured habitat and shelter against predators (Sanpera-Calbet et al. 2009, Jabiol et al. 2014). 
Thus, according to these mechanisms, litter-mixture effects would be more prevalent in litter accumulations containing litter species that have contrasting litter traits, an expectation recently confirmed by a large-scale analysis (Lecerf et al. 2011).

Our knowledge about litter decomposition and particularly about effects of litter mixtures on decomposition is derived mostly from experiments carried out in temperate streams (Graça and Canhoto 2006). Very few investigators have addressed effects of litter mixtures in streams at higher or lower latitudes. For example, Mediterranean streams have never been fully assessed despite evidence that Mediterranean climatic and biotic features may influence rates of ecosystem processes. Mediterranean climates are characterized by cold and wet winters contrasting with hot and dry summers. This climate induces consistent plant adaptations against summer droughts (King et al. 1987, Britton 1990, Stewart and Davies 1990). These include thick and dense leaf tissue (i.e., sclerophyllous) resulting from high concentrations of structural compounds (Kazakou et al. 2009) and chemical and structural antiherbivore defenses (Grime et al. 1996), both of which may slow the decomposition process (Turner 1994, Aerts 1995). Mediterranean sclerophyllous and evergreen vegetation may co-occur with deciduous species on stream banks where plants benefit from year-round moisture (Holstein 1984, Maamri et al. 1994). This mixture of sclerophyllous and deciduous riparian vegetation results in a more prolonged period of litter fall that extends from summer (sclerophyllous trees) to autumn (deciduous trees) (Maamri et al. 1994, Acuña et al. 2007) and greater litter-trait dissimilarity than observed in most temperate streams. Both of these features should increase the potential for litter-mixture effects on decomposition (Lecerf et al. 2011).

Macroinvertebrate communities in Mediterranean headwater streams also differ from those in temperate streams. Hydrological regimes under Mediterranean climate are characterized by high seasonal variability in discharge, which leads to alternating seasonal periods of summer drought and winter floods (Aschmann 1973). These severe, but predictable perturbations constitute a strong selection pressure for macroinvertebrates, which influences various life-history traits and may favor macroinvertebrates with short life cycles and small body sizes (Bêche et al. 2006, Bonada et al. 2007). Moreover, theoretical predictions about latitudinal patterns of stream detritivore communities (Boyero et al. 2011) and field data (e.g., Essafi et al. 1994, Maamri et al. 1997, Graça et al. 2004, Gonçalves et al. 2006) suggest that the abundance and diversity of leaf-eating insect larvae might be lower in Mediterranean streams than in temperate ones. Thus, low detritivore biomass and diversity should result in a low contribution of detritivores to litter decomposition (Gasith and Resh 1999) and weak effects of litter mixtures. Study- ing litter-mixture effects in Mediterranean streams, in which high litter-trait dissimilarity and low shredder abundance co-occur, should help to shed light on the relative importance of these factors and the functioning of such stream ecosystems.

We used 4 leaf-litter species that differ in litter traits to examine effects of litter mixture in a French Mediterranean headwater stream. We assessed rates of litter decomposition in all possible combinations of $1,2,3$, and 4 species. In addition, we used litter bags with different mesh sizes to evaluate the respective contributions of microorganisms and small vs large body-sized macroinvertebrates to the decomposition process and to effects of litter mixture. We expected that: 1) mixing contrasted litter species would promote effects of litter mixtures on decomposition when detritivores had access to the litter, 2) unless detritivore density was too low to allow such effects to occur. Last, 3) because invertebrates are expected to be small, the contribution of small detritivores should be substantial compared with that of larger ones.

\section{METHODS \\ Study site}

We conducted the experiment in the Maureillas, an oligotrophic permanent stream in the French Pyrenean piedmont (lat $02^{\circ} 47^{\prime} 57^{\prime \prime} \mathrm{E}$, long $42^{\circ} 28^{\prime} 17^{\prime \prime} \mathrm{N}$; elevation: $200 \mathrm{~m}$ asl). Temperature was monitored continuously during the experiment with data loggers (Smart-Button; ACR System, Surrey, Canada) and ranged between 1.9 and 11.3 ${ }^{\circ} \mathrm{C}$ (mean: $5.7^{\circ} \mathrm{C} \pm 2.2 \mathrm{SD}$ ) in November-December 2007. The stream bottom consists of hard substrata (boulders and bedrock), and the surrounding Mediterranean forest is dominated by Quercus ilex (L.). Other plant species encountered in the surroundings include Pistacia terebinthus L., Quercus suber L., Arbutus unedo L. Additional species that occur on the stream banks are Alnus glutinosa (L.) Gaertn., Fraxinus angustifolia (Vahl), Acer campestre (L.), and Corylus avellana (L.).

\section{Experimental design}

We selected 4 litter species (alder: A. glutinosa, ash: F. angustifolia, pistachio: $P$. terebinthus L., and evergreen oak: Q. ilex) that differed in litter traits (Table 1). Methods used to measure trait values were described by Makkonen et al. (2012) except for leaf toughness, which we measured with a precision penetrometer $(\varnothing=1.5 \mathrm{~mm}$; C-2006 MKII; Connolly, Townsville, Australia; Pearson and Connolly 2000). We collected leaves just after abscission and dried them at $40^{\circ} \mathrm{C}$ prior to initial weighing. We enclosed a total of $5 \mathrm{~g}$ of litter (weighed to the nearest $0.01 \mathrm{~g}$ ) in each litter bag. Litter bags included all possible species combinations (4 single-species treatments, 6 two-species mixtures, 4 three-species mixtures, and 1 four-species mixture). We 
Table 1. Mean $( \pm \mathrm{SD})$ trait values of the 4 litter species. All values are expressed in \% litter dry mass except for leaf toughness ( $g$ ). $n=10$ for leaf toughness, $n=3$ for all other traits.

\begin{tabular}{lcccccccc}
\hline \multicolumn{1}{c}{ Species } & $\mathrm{N}$ & $\mathrm{P}$ & $\mathrm{C}$ & Cellulose & Hemi-cellulose & Lignin & Condensed tannins & Toughness \\
\hline Alnus glutinosa & $1.7 \pm 0.1$ & $0.04 \pm 0.00$ & $46.1 \pm 0.3$ & $21.6 \pm 1.7$ & $12.0 \pm 0.4$ & $8.9 \pm 0.3$ & $0.7 \pm 0.1$ & $107 \pm 18$ \\
Pistacia terebinthus & $0.5 \pm 0.0$ & $0.14 \pm 0.02$ & $49.1 \pm 0.3$ & $15.2 \pm 1.2$ & $12.0 \pm 0.4$ & $11.8 \pm 0.6$ & $3.7 \pm 0.6$ & $184 \pm 34$ \\
Fraxinus angustifolia & $1.0 \pm 0.1$ & $0.04 \pm 0.00$ & $47.0 \pm 0.3$ & $19.3 \pm 3.9$ & $13.1 \pm 0.3$ & $11.1 \pm 0.1$ & $0.1 \pm 0.0$ & $93 \pm 29$ \\
Quercus ilex & $0.7 \pm 0.1$ & $0.04 \pm 0.00$ & $48.6 \pm 0.1$ & $18.4 \pm 0.3$ & $19.5 \pm 0.2$ & $15.1 \pm 0.4$ & $1.9 \pm 0.1$ & $441 \pm 118$ \\
\hline
\end{tabular}

constructed litter bags of 3 different mesh sizes $(0.25,1$, and $5 \mathrm{~mm}$ ) to exclude decomposers according to their body size. Small-mesh bags allowed access by microorganisms only (i.e., fungi and bacteria), medium mesh allowed access by microorganisms and small-sized invertebrates, and coarse mesh allowed access by the entire decomposer community, including the largest detritivores in the stream community (larvae of Limnephilidae and Calamoceratidae, Trichoptera). We made all litter mixture $\times$ mesh size combinations and replicated them 5 times in blocks in distant $(\geq 50 \mathrm{~m}$ ) sections of the stream.

We deployed litter bags in the Maureillas in late November 2007 and harvested them after $46 \mathrm{~d}$. This period corresponds to 30 to $50 \%$ of initial mass remaining for F. angustifolia (the fastest decomposing species) in coarsemesh bags (measured by extrapolation of the litter massloss kinetics observed with 2 additional batches of 3 coarsemesh bags filled with $F$. angustifolia litter and retrieved from the stream after 14 and $28 \mathrm{~d}$ ). After collection, we sorted leaves by species and carefully removed macroinvertebrates and fine particulate matter. We weighed leaf material from each species and litter bag separately after drying at $65^{\circ} \mathrm{C}$ to constant mass. We preserved macroinvertebrates in $70^{\circ} \mathrm{C}$ ethanol. We counted and identified detritivores to the genus level with the aid of a dissecting microscope $(20-80 \times)$ and an identification key (Tachet et al. 2000).

\section{Leaf mass loss and detritivore communities}

We measured leaf mass loss after the $46 \mathrm{~d}$ of exposure in the stream for each litter mixture and individual species as the difference between initial and final litter dry mass, and expressed it as \% of initial dry mass. To allow comparisons of leaf-litter decomposition in single-species treatments vs mixtures, we calculated 2 complementary metrics. First, the difference between observed $(O)$ and expected $(E)$ leaf mass loss, with $O$ being the \% leaf mass loss of the given mixture and $E$ the average \% leaf mass loss of each corresponding species in single-species treatments, allowed us to assess whether mixing litter species had a net influence on decomposition rates. The $2^{\text {nd }}$ metric was calculated as the difference between $M$ and $S$, with $M$ being the \% leaf mass loss of a given species in a mixture and $S$ the \% leaf mass loss of the same species from single-species treatments. This metric allowed us to identify litter species that decomposed at different rates in mixtures than in singlespecies treatments and, thus, determined the magnitude of $O-E$ effects. Both metrics are positive when leaf mass loss is increased by mixing litter species. Last, detritivore density was calculated in medium- and coarse-mesh-bag treatments as the number of individuals/g of remaining litter dry mass.

\section{Statistical analyses}

We used hierarchical analyses of variance (ANOVAs) at the leaf-pack level to assess the significance of the effects of mesh size, litter species combinations, and their interactions on several response variables including leaf mass loss, litter-mixture effect, and detritivore density. Both littermixture (i.e., comparison between single-species treatments vs mixtures) and litter diversity (i.e., effect of the number of species) contrasts were included in the analyses (except for mixture effect where only the litter-diversity contrast was included), and nested in litter species composition term (i.e., effect of a particular combination of litter species) to avoid pseudoreplication. The block effect and its interaction with litter treatment and mesh size were included as error terms.

At the individual litter-species level, we used an ANOVA to assess the significance of litter-species identity and mesh size on the litter-mixture effect. We included block and its interaction with mesh size as error terms. Leaf mass loss and detritivore density were $\log (x)$-transformed in the model above to meet ANOVA assumptions. All statistics were performed using $\mathrm{R}$ (version 3.0.0; $\mathrm{R}$ Project for Statistical Computing, Vienna, Austria).

\section{RESULTS}

Leaf mass loss

After $46 \mathrm{~d}$ of exposure in the Maureillas, the mass loss of single litter species in coarse-mesh bags differed among litter species, and was highest for ash $(57.2 \pm 7.9 \%$ of initial mass [SD]) and alder (38.0\% \pm 3.5$)$, and lower for pistachio $(20.4 \pm 2.2 \%)$ and evergreen oak $(17.6 \% \pm 1.3)$. Leaf mass loss depended on mesh size (Table 2 ) and was primarily 
Table 2. Analysis of variance results for the effects of litter mixture, litter diversity, and litter-bag mesh size on $\log (x)$-transformed leaf mass loss, litter-mixture effect, and $\log (x)$-transformed detritivore density. Each treatment term (litter mixture, litter diversity, and mesh size) was tested against an error term that included litter species composition, block effect, and their interactions. E/F column indicates whether the factor is included as a factor $(\mathrm{F})$ or error term $(\mathrm{E})$. SS = sum of squares.

\begin{tabular}{|c|c|c|c|c|c|c|c|c|c|c|}
\hline \multirow[b]{2}{*}{ Source } & \multirow[b]{2}{*}{$\mathrm{E} / \mathrm{F}$} & \multicolumn{3}{|c|}{ Leaf mass loss } & \multicolumn{3}{|c|}{ Mixture effect } & \multicolumn{3}{|c|}{ Detritivore density } \\
\hline & & df & SS & $p$-value & df & SS & $p$-value & df & SS & $p$-value \\
\hline Block & E & 4 & 0.97 & $<0.001$ & 4 & 545.2 & $<0.001$ & 4 & 2.05 & 0.111 \\
\hline Litter mixture & $\mathrm{F}$ & 1 & 0.86 & 0.478 & - & - & - & 1 & 0.27 & 0.528 \\
\hline Litter diversity & $\mathrm{F}$ & 1 & 0.07 & 0.839 & 1 & 8.8 & 0.582 & 1 & 0.43 & 0.426 \\
\hline Litter-species composition & E & 12 & 19.10 & $<0.001$ & 9 & 253.0 & 0.193 & 12 & 7.63 & 0.012 \\
\hline Mesh size & $\mathrm{F}$ & 2 & 1.33 & $<0.001$ & 2 & 251.0 & 0.017 & 1 & 12.40 & $<0.001$ \\
\hline Mesh size $\times$ litter mixture & $\mathrm{F}$ & 2 & 0.05 & 0.181 & - & - & - & 1 & 0.10 & 0.639 \\
\hline Mesh size $\times$ litter diversity & $\mathrm{F}$ & 2 & $<0.01$ & 0.900 & 2 & 1.6 & 0.968 & 1 & 0.64 & 0.243 \\
\hline Litter-species composition $\times$ mesh size & E & 24 & 0.36 & 0.085 & 18 & 693.1 & 0.222 & 12 & 5.08 & 0.108 \\
\hline Block $\times$ litter species composition & E & 56 & 0.87 & 0.025 & 40 & 1253.4 & 0.030 & 56 & 10.13 & 0.909 \\
\hline Block $\times$ mesh size & E & 8 & 0.12 & 0.182 & 8 & 349.7 & 0.029 & 4 & 1.72 & 0.172 \\
\hline Residuals & E & 112 & 1.13 & & 80 & 1526.2 & & 56 & 14.51 & \\
\hline
\end{tabular}

caused by microbial activity. Leaf mass loss in small-mesh bags explained an average of $85.8 \%$ of the total leaf mass loss (Fig. 1). Increasing mesh size led to an increase in leaf mass loss of 0.6 and $16.5 \%$ for medium- and coarse-mesh bags, respectively. This increase, which accounts for the respective contribution of small and large macroinvertebrates to decomposition, depended on litter species composition and was the strongest on ash single species $(2.7$ and $23.3 \%$ for small and large invertebrates, respectively) and ash-alder mixture (20.4 and 3.1\% for small and large invertebrates, respectively) (Fig. 1). On average, neither litter mixture nor diversity influenced litter decomposition because of the inconsistency of the litter-mixture effect, which depended on the block and the combination of litter species (Table 2).

In accordance with the nonsignificant net effect of litter mixture on decomposition, leaf mass loss in litter mixtures was always intermediate between the values in corresponding single-species treatments (Fig. 1). Nevertheless, the effect of litter mixture on decomposition was influenced by the mesh size of the litter bags (Table 2, Fig. 2A, B). Positive litter-mixture effects, corresponding to an increased leaf mass loss, occurred in coarse- $(3.3 \pm 0.8 \%$ [SE] $)$ and medium- $(3.3 \pm 0.7 \%$ [SE] $)$ but not small-mesh bags $(0.7 \pm 0.5 \%[\mathrm{SE}])$. Mixture effects were strongest in alder-ash mixtures and weakest in pistachio-oak mixtures (i.e., the only mixture than contained no labile litter species) (Fig. 2A, B). Increased decomposition of litter mixtures was the result of increased leaf mass loss of alder and ash (but not pistachio and oak) in mixtures (Fig. 2B). Increased leaf mass loss of alder litter in mixtures occurred mainly in medium- and coarse-mesh bags, whereas it occurred in all mesh sizes for ash litter (Fig. 2B), resulting in significant effects of species identity and species identity $x$ mesh size on the litter-mixture effect at the individualspecies level (Table 3).

\section{Detritivore communities}

The dominant detritivore taxa in the litter bags were Capnioneura and Lepidostoma (63.0\% and 23.8\% of individuals, respectively). Other detritivore taxa belonged to Trichoptera (Limnephilidae, Sericostomatidae, Leptoceridae, and Calamoceratidae), Plecoptera (Nemouridae and Taeniopterygidae), Diptera (Tipulidae), and Isopoda (Asellidae).

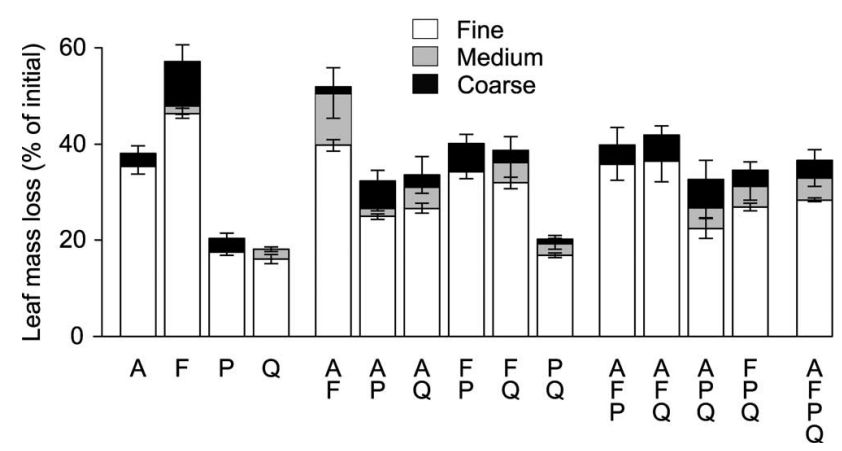

Figure 1. Mean $( \pm 1 \mathrm{SE} ; n=5)$ leaf mass loss (\% of initial dry mass) in each litter-species combination and litter-bag mesh size. Litter combinations are given by the initial of the litter species $(\mathrm{A}=$ Alnus, $\mathrm{F}=$ Fraxinus, $\mathrm{P}=$ Pistacia, $\mathrm{Q}=$ Quercus $)$. Stacking the bars from fine- to coarse-mesh bags illustrates the average contribution of microorganisms, small invertebrates, and large invertebrates to leaf mass loss. In some treatments, the contribution of small invertebrates is not shown because leaf mass was higher in fine- than in medium-mesh bags. 


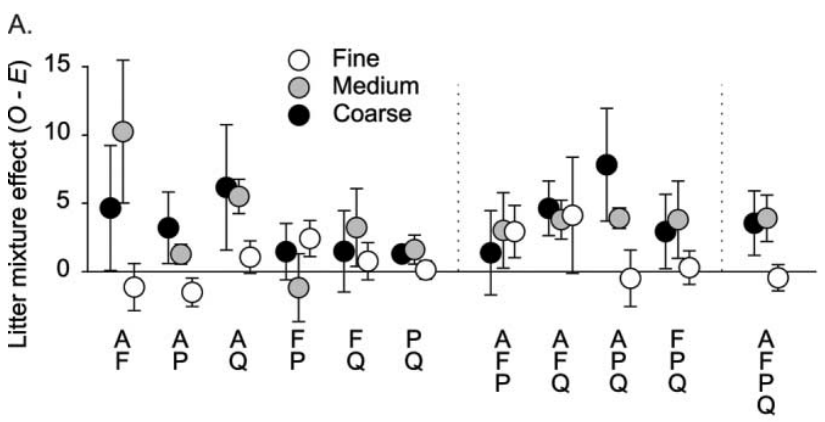

B.

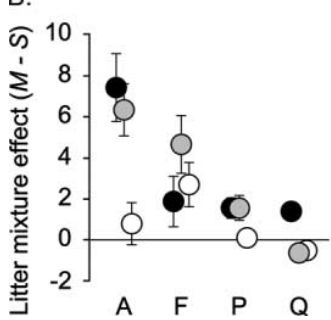

Figure 2. Mean $( \pm 1 \mathrm{SE} ; \mathrm{A}: n=5$, B: $n=35)$ litter-mixture effect at the litter-accumulation level $(O-E$; where $O=\%$ leaf mass loss of the mixture, $E=$ average \% leaf mass loss of each constituent species in its single-species treatment) (A) and at the individual litter-species level $(M-S$; where $M=\%$ leaf mass loss of a given species in a mixture, $S=\%$ leaf mass loss of the same species in its single-species treatment) (B) in the different litter and mesh treatments. Litter combinations are given by the initial of the litter species $(\mathrm{A}=$ Alnus, $\mathrm{F}=$ Fraxinus, $\mathrm{P}=$ Pistacia, $\mathrm{Q}=$ Quercus $)$.

Medium-mesh bags had lower detritivore density than coarse-mesh bags (Fig. 3; Table 2) and were accessible only to the smallest individuals, including small Trichoptera (Lepidostoma, Leptoceridae, and early instars of Limnephilidae larvae) and Plecoptera (Capnioneura and Taeniopterygidae larvae). On average, detritivore density was not influenced by litter mixture or diversity, but like litter decomposition, depended on the species composition of the litter bag (Table 2). In coarse-mesh bags, detritivore densities were highest in ash single-species treatments $(9.0 \pm 6.3$ individuals/g litter [SD]) and in alder-ash mixtures (12.6 \pm 3.2 individuals/g litter). In medium-mesh bags, densities of detritivores were highest in alder-ash-oak (5.6 \pm 3.0 individuals/g of litter) and in the 4-species mixtures (4.2 \pm 1.2 individuals/g of litter).

\section{DISCUSSION}

Litter mixture influenced leaf decomposition in the Maureillas, a French Mediterranean headwater stream, at a magnitude similar to those found in studies done in temperate latitudes (Lecerf et al. 2011). As in other studies, the influence of litter mixture on decomposition was either positive, negative, or nil depending on the context. Litter-mixture effects typically occurred when litter spe- cies of contrasting degradability (e.g., alder and evergreen oak) were mixed (Kominoski et al. 2009, Sanpera-Calbet et al. 2009) and were contingent on the presence of detritivores (Swan and Palmer 2006). This result suggests that processes operating in temperate streams also are important in Mediterranean streams. However, some patterns in our study were unexpected based on reports from temperate studies. For example, the largest mixture effect occurred in litter packs containing the combination of our 2 softest litter species (alder and ash), which were not as dissimilar as other litter-species combinations. Moreover, we found a contribution of microbial decomposers to litter decomposition that greatly exceeded our expectations based on literature data on temperate streams. Thus, the same processes occur in Mediterranean and temperate streams (e.g., microbial degradation and litter breakdown by detritivores), but they differ in their relative strengths, which could have important implications for stream ecosystem functioning.

Despite the high contribution of microbes to litter decomposition compared to the contribution of detritivores, litter-mixture effects on decomposition occurred only in mesh bags that allowed access to invertebrates and were weak or absent when invertebrate consumers were excluded. This result suggests that the activity of microbial decomposers alone did not lead to any effect of litter mixture on decomposition. On the contrary, it means that effects of litter mixture depend on detritivore activity, even when their density is lower than usually observed at higher latitudes (e.g., Malmqvist et al. 1978, Hieber and Gessner 2002). The relatively low abundance of detritivores in the Maureillas is in accordance with results published by Boyero et al. (2011), who suggested that typical leaf-eating insect larvae could be scarcer in Mediterranean than in temperate streams. Low detritivore abundance may result in slow litter decomposition when other groups of detritivores (e.g., Mediterranean detritivorous gastropods; Chergui and Pattée 1991, Casas et al. 2011) do not

Table 3. Analysis of variance results for the effects of litter species identity and mesh size on the litter-mixture effect at the individual-species level. Block effect and its interaction with mesh size were included as error terms. E/F column indicates whether the factor is included as a factor (F) or error term (E). SS = sum of squares.

\begin{tabular}{lcrrr}
\hline & E/F & df & \multicolumn{1}{c}{ SS } & $p$-value \\
\hline Block & E & 4 & 1641 & $<\mathbf{0 . 0 0 1}$ \\
$\quad$ Mesh size & F & 2 & 630 & 0.130 \\
Block $\times$ mesh size & E & 8 & 945 & 0.002 \\
$\quad$ Species & F & 3 & 1880 & $<\mathbf{0 . 0 0 1}$ \\
$\quad$ Species $\times$ mesh size & F & 6 & 934 & $<\mathbf{0 . 0 0 1}$ \\
Residuals & E & 396 & 14,638 & \\
\hline
\end{tabular}




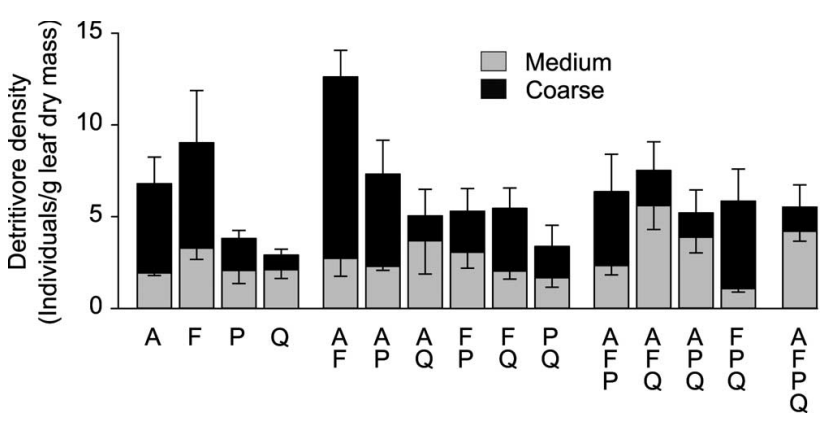

Figure 3. Mean $( \pm 1 \mathrm{SE} ; n=5)$ detritivore density (individuals/g litter dry mass) in coarse- and medium-mesh bags. Litter combinations are given by the initial of the litter species $(\mathrm{A}=$ Alnus, $\mathrm{F}=$ Fraxinus, $\mathrm{P}=$ Pistacia, $\mathrm{Q}=$ Quercus $)$. Stacking the bars illustrates the average contribution of small and large detritivores to the density of invertebrate communities.

occur. Accordingly, we found that the contribution of detritivores to litter decomposition in our Mediterranean stream (14.2\%) was lower than in temperate streams (up to $60 \%$; e.g., Hieber and Gessner 2002). This result also supports the conclusions by Gonçalves et al. (2006) who found the contribution of detritivores to leaf mass loss more important in a temperate than in a Mediterranean stream.

Positive effects of litter mixture on decomposition were not observed in all litter treatments. Their occurrence depended on the species composition of the litter pack, and the strongest increases in litter decomposition were observed when alder was mixed with ash and, to a lesser extent, with oak litter (e.g., alder-ash, alder-oak, alder-pistachio-oak). Higher decomposition rates at the litter-pack level caused by increased depletion of the labile litter (alder or ash) in the mixture probably resulted from different mechanisms. Increased decomposition of alder when mixed with oak may reflect mechanisms that have been evoked repeatedly in the literature on littermixture effects in temperate streams. In mixtures containing both labile and refractory litter species (e.g., alderoak mixtures), detritivores may have focused intensely on the most labile litter species, thereby increasing its decomposition (Swan and Palmer 2006). At the same time, high detritivore density is promoted by the co-occurrence of a suitable resource (provided by the labile litter) and a complex and structured habitat provided by the refractory litter (Sanpera-Calbet et al. 2009, Jabiol et al. 2014). The observed increases in leaf mass loss in ash-alder litter packs are more intriguing and probably result from other mechanisms because these litter species are both soft and palatable for detritivores. For instance, differences in $\mathrm{N}$ concentration between litter species could lead to some transfer of $\mathrm{N}$ from alder ( $\mathrm{N}$ rich) to ash ( $\mathrm{N}$ poor) litter, thereby increasing the decomposition of ash litter, as described in detrital ecosystems (Schimel and Hättenschwiler 2007, Handa et al. 2014).
Contrary to our hypothesis, we did not observe a prevalence of medium-sized detritivores in the decomposition process. On average, their density was similar to that of larger ( $>5 \mathrm{~mm}$ body length) detritivores, a result suggesting that the total biomass of medium-sized detritivores was much lower because of a lower per capita biomass. Thus, their contribution to leaf mass loss (and litter-mixture effects) was often lower than the contribution of larger invertebrates. However, in some treatments, the leaf mass loss in medium-mesh bags was unexpectedly high given the low density of medium-sized detritivores, perhaps because of some other invertebrate taxa that dominated the communities in medium-mesh bags but are not usually considered as detritivores, such as Micrasema sp. and various species of chironomids. These taxa had higher density in medium- than in coarse-mesh bags, which is probably the result of a decreased predation rate because of the exclusion of large predators. The relatively high contribution of leaf mass loss by small invertebrates could have been promoted by some species of chironomids, which can use leaf litter as a complementary food resource (Callisto et al. 2007). Alternatively, their activity, together with that of Micrasema (which have a mineral case), could have increased the physical abrasion of the litter, thereby increasing leaf mass loss in medium-mesh litter bags.

According to predictions by Gasith and Resh (1999), dominance of small-sized invertebrates should be exacerbated when stream flow undergoes strong variations, such as droughts or floods, and be less prevalent in permanent streams, such as the Maureillas. Streams in Mediterranean climates exhibit a high diversity of hydrological and biological conditions. Additional studies are needed to encompass the huge intra- and intercontinental variations in Mediterranean stream hydrology, biodiversity, and ecosystem processes. Specifically, the low abundance of detritivores relative to abundances in temperate streams is of particular importance because it may translate to slower litter decomposition or higher contribution of microorganisms to litter decomposition. Nevertheless, our results suggest that the contribution of macroinvertebrates is important because it may interact with riparian tree diversity. In addition to the low abundance of detritivores in Mediterranean streams, the vegetation of this region often exhibits traits that slow the decomposition of its litter, and litter standing stocks are periodically relocated by flood events. As a result, the efficiency of $\mathrm{C}$ and nutrient cycling in these streams is contingent on the presence of a few species, including easily decomposed litter species and large detritivores, that insure rapid elemental immobilization in the food web. We suggest that these ecosystems, probably more than their temperate counterparts, are particularly sensitive to perturbations, including climate change and riparian forest management. For example, as a result of the low detritivore diversity, the extinction of a few macroin- 
vertebrate taxa would easily lead to the extinction of the entire trophic guild (Boyero et al. 2012). Similarly, degradation of the riparian labile vegetation in favor of sclerophyllous tree species (e.g., eucalypt plantations) (Abelho and Graça 1996) could have severe consequences for nutrient and $\mathrm{C}$ fluxes in Mediterranean streams.

\section{ACKNOWLEDGEMENTS}

We thank Sylvain Lamothe, Didier Lambrigot, Julien Cornut, and Andreas Bruder for technical assistance. We especially acknowledge Laurette Sonié, Jasper van Ruijven, Stephan Hättenschwiler, Tanya Handa, Mathieu Coulis, and Soraya Rouifed, who analyzed leaf-litter chemistry. We also thank Tanya Handa, Associate Editor Manuel Graça, and 2 anonymous referees for constructive comments on the manuscript. Project funding was provided by the French National Centre for Scientific Research (CNRS) in support of the collaborative research project BioCycle of the European Science Foundation's (ESF) EuroCORES programme EuroDIVERSITY. BioCycle has been endorsed by DIVERSITAS as contributing toward its research priorities in biodiversity science.

\section{LITERATURE CITED}

Abelho, M., and M. A. S. Graça. 1996. Effects of eucalyptus afforestation on leaf litter dynamics and macroinvertebrate community structure of streams in Central Portugal. Hydrobiologia 324:195-204.

Acuña, V., A. Giorgi, I. Muñoz, F. Sabater, and S. Sabater. 2007. Meteorological and riparian influences on organic matter dynamics in a forested Mediterranean stream. Journal of the North American Benthological Society 26:54-69.

Aerts, R. 1995. The advantages of being evergreen. Trends in Ecology and Evolution 10:402-407.

Aschmann, H. 1973. Distribution and peculiarity of Mediterranean ecosystems. Pages 11-20 in F. di Castri and H. A. Mooney (editors). Mediterranean type ecosystems: origin and structure. Springer-Verlag, Berlin, Germany.

Bêche, L. A., E. P. McElravy, and V. H. Resh. 2006. Longterm seasonal variation in the biological traits of benthicmacroinvertebrates in two Mediterranean climate streams in California, U.S.A. Freshwater Biology 51:56-75.

Berg, B., and C. McClaugherty. 2008. Plant litter: decomposition, humus formation, carbon sequestration. Springer-Verlag, Berlin, Germany.

Bonada, N., S. Dolédec, and B. Statzner. 2007. Taxonomic and biological trait differences of stream macroinvertebrate communities between Mediterranean and temperate regions: implications for future climatic scenarios. Global Change Biology 13:1658-1671.

Boyero, L., R. G. Pearson, D. Dudgeon, V. Ferreira, M. A. S. Graça, M. O. Gessner, A. J. Boulton, E. Chauvet, C. M. Yule, R. J. Albariño, A. J. Ramírez, J. E. Helson, M. Callisto, M. Arunachalam, J. Chará, R. Figueroa, J. M. Mathooko, J. F. Gonçalves, M. S. Moretti, A. M. Chará-Serna, J. N. Davies, A. C. Encalada, S. Lamothe, L. M. Buria, J. Castela, A. Cornejo, A. O. Y. Li, C. M. Erimba, V. D. Villanueva, and C. Zúñiga. 2012. Global patterns of distribution in stream detritivores: implications for biodiversity loss in changing climates. Global Ecology and Biogeography 21:134-141.

Boyero, L., R. G. Pearson, D. Dudgeon, M. A. S. Graça, M. O. Gessner, R. Albariño, V. Ferreira, C. M. Yule, A. J. Boulton, M. Arunachalam, M. Callisto, E. Chauvet, A. Ramírez, J. Chará, M. S. Moretti, J. F. Gonçalves, J. E. Helson, A. M. Chará-Serna, A. C. Encalada, J. N. Davies, S. Lamothe, A. Cornejo, A. O. Y. Li, L. M. Buria, V. D. Villanueva, C. Zúñiga, and C. M. Pringle. 2011. Global distribution of a key trophic guild contrasts with common latitudinal diversity patterns. Ecology 92:1839-1848.

Britton, D. L. 1990. Fire and the dynamics of allochthonous detritus in a South African mountain stream. Freshwater Biology 24:347-360.

Callisto, M., J. F. Gonçalves, and M. A. S. Graça. 2007. Leaf litter as a possible food source for chironomids (Diptera) in Brazilian and Portuguese headwater streams. Revista Brasileira de Zoologia 24:442-448.

Casas, J. J., M. O. Gessner, D. López, and E. Descals. 2011. Leaf-litter colonisation and breakdown in relation to stream typology: insights from Mediterranean low-order streams. Freshwater Biology 56:2594-2608.

Cebrian, J. 1999. Patterns in the fate of production in plant communities. American Naturalist 154:449-468.

Chergui, H., and E. Pattée. 1991. An experimental study of the breakdown of submerged leaves by hyphomycetes and invertebrates in Morocco. Freshwater Biology 26:97-110.

Essafi, K., H. Chergui, E. Pattée, and J. Mathieu. 1994. The breakdown of dead leaves buried in the sediment of a permanent stream in Morocco. Archiv für Hydrobiologie 130:105-112.

Gasith, A., and V. H. Resh. 1999. Streams in Mediterranean climate regions: abiotic influences and biotic responses to predictable seasonal events. Annual Review of Ecology and Systematics 30:51-81.

Gessner, M. O., and E. Chauvet. 1994. Importance of stream microfungi in controlling breakdown rates of leaf litter. Ecology 75:1807-1817.

Gessner, M. O., C. M. Swan, C. K. Dang, B. G. McKie, R. D. Bardgett, D. H. Wall, and S. Hättenschwiler. 2010. Diversity meets decomposition. Trends in Ecology and Evolution 25: 372-380.

Gonçalves, J. F., M. A. S. Graça, and M. Callisto. 2006. Leaflitter breakdown in 3 streams in temperate, Mediterranean, and tropical Cerrado climates. Journal of the North American Benthological Society 25:344-355.

Graça, M. A. S., and C. Canhoto. 2006. Leaf litter processing in low order streams. Limnetica 25:1-10.

Graça, M. A. S., P. Pinto, R. Cortes, N. Coimbra, S. Oliveira, M. Morais, M. J. Carvalho, and J. Malo. 2004. Factors affecting macroinvertebrate richness and diversity in Portuguese streams: a two-scale analysis. International Review of $\mathrm{Hy}-$ drobiology 89:151-164.

Grime, J. P., J. H. C. Cornelissen, K. Thompson, and J. G. Hogdson. 1996. Evidence of a causal connection between antiherbivore defense and the decomposition rate of leaves. Oikos 77:489-494.

Handa, I. T., R. Aerts, F. Berendse, M. P. Berg, A. Bruder, O. Butenschoen, E. Chauvet, M. O. Gessner, J. Jabiol, M. Makkonen, B. G. McKie, B. Malmqvist, E. T. H. M. Peeters, S. Scheu, B. Schmid, J. van Ruijven, V. C. A. Vos, 
and S. Hättenschwiler. 2014. Consequences of biodiversity loss for decomposition across biomes. Nature 509:218-221.

Hättenschwiler, S., A. V. Tiunov, and S. Scheu. 2005. Biodiversity and litter decomposition in terrestrial ecosystems. Annual Review of Ecology, Evolution, and Systematics 36:191-218.

Hieber, M., and M. O. Gessner. 2002. Contribution of stream detritivores, fungi, and bacteria to leaf breakdown based on biomass estimates. Ecology 83:1026-1038.

Holstein, G. 1984. California riparian forests: deciduous islands in an evergreen sea. Pages 2-22 in R. E. Warner and K. M. Hendrix (editors). California riparian systems: ecology, conservation, and productive management. University of California Press, Berkeley, California.

Jabiol, J., and E. Chauvet. 2012. Fungi are involved in the effects of litter mixtures on consumption by shredders. Freshwater Biology 57:1667-1677.

Jabiol, J., J. Cornut, M. Danger, M. Jouffroy, A. Elger, and E. Chauvet. 2014. Litter identity mediates predator impacts on the functioning of an aquatic detritus-based food web. Oecologia (Berlin) 176:255-235.

Kazakou, E., C. Violle, C. Roumet, C. Pintor, O. Gimenez, and E. Garnier. 2009. Litter quality and decomposability of species from a Mediterranean succession depend on leaf traits but not on nitrogen supply. Annals of Botany 104:1151-1161.

King, J. M., J. A. Day, B. R. Davies, and M.-P. HenshallHoward. 1987. Particulate organic matter in a mountain stream in the south-western Cape, South Africa. Hydrobiologia 154:165-187.

Kominoski, J. S., T. J. Hoellein, J. J. Kelly, and C. M. Pringle. 2009. Does mixing litter of different qualities alter stream microbial diversity and functioning on individual litter species? Oikos 118:457-463.

Lecerf, A., G. Marie, J. S. Kominoski, C. J. LeRoy, C. Bernadet, and C. M. Swan. 2011. Incubation time, functional litter diversity, and habitat characteristics predict litter mixing effects on decomposition. Ecology 92:160-169.

Lecerf, A., G. Risnoveanu, C. Popescu, M. O. Gessner, and E. Chauvet. 2007. Decomposition of diverse litter mixtures in streams. Ecology 88:219-227.

LeRoy, C. J., and J. C. Marks. 2006. Litter quality, stream characteristics and litter diversity influence decomposition rates and macroinvertebrates. Freshwater Biology 51:605-617.

Maamri, A., H. Chergui, and E. Pattée. 1994. Allochthonous input of coarse particulate organic matter to a Moroccan mountain stream. Acta Oecologica 15:495-508.
Maamri, A., H. Chergui, and E. Pattée. 1997. Leaf litter processing in a temporary northeastern Moroccan river. Archiv für Hydrobiologie 140:513-531.

Makkonen, M., M. P. Berg, I. T. Handa, S. Hättenschwiler, J. van Ruijven, P. M. van Bodegom, and R. Aerts. 2012. Highly consistent effects of plant litter identity and functional traits on decomposition across a latitudinal gradient. Ecology Letters 15:1033-1041.

Malmqvist, B., L. M. Nilsson, B. S. Svensson. 1978. Dynamics of detritus in a small stream in southern Sweden and its influence on the distribution of the bottom animal communities. Oikos 31:3-16.

Melillo, J. M., J. D. Aber, and J. F. Muratore. 1982. Nitrogen and lignin control of hardwood leaf litter decomposition dynamics. Ecology 63:621-626.

Pearson, R. G., and N. M. Connolly. 2000. Nutrient enhancement, food quality and community dynamics in a tropical rainforest stream. Freshwater Biology 43:31-42.

Sanpera-Calbet, I., A. Lecerf, and E. Chauvet. 2009. Leaf diversity influences in-stream litter decomposition through effects on shredders. Freshwater Biology 54:1671-1682.

Schimel, J. P., and S. Hättenschwiler. 2007. Nitrogen transfer between decomposing leaves of different $\mathrm{N}$ status. Soil Biology and Biochemistry 39:1428-1436.

Stewart, B. A., and B. R. Davies. 1990. Allochthonous input and retention in a small mountain stream, South Africa. Hydrobiologia 202:135-146.

Swan, C. M., B. Healey, and D. C. Richardson. 2008. The role of native riparian tree species in decomposition of invasive tree of heaven (Ailanthus altissima) leaf litter in an urban stream. Ecoscience 15:27-35.

Swan, C. M., and M. A. Palmer. 2004. Leaf diversity alters litter breakdown in a Piedmont stream. Journal of the North American Benthological Society 23:15-28.

Swan, C. M., and M. A. Palmer. 2006. Preferential feeding by an aquatic consumer mediates non-additive decomposition of speciose leaf litter. Oecologia (Berlin) 149:107-114.

Tachet, H., P. Richoux, M. Bournaud, and P. Usseglio-Polatera. 2000. Invertébrés d'eau douce: systématique, biologie, écologie. CNRS Edition, Paris, France.

Turner, I. M. 1994. Sclerophylly: primarily protective? Functional Ecology 8:669-675.

Wallace, J. B., S. L. Eggert, J. L. Meyer, and J. R. Webster. 1997. Multiple trophic levels of a forest stream linked to terrestrial litter inputs. Science 277:102-104. 